Грицевич, Юрій. «Фольклорні записи Оскара Кольберга як простір вияву діалектних явищ (на матеріалі двотомника „Chełmskie”)». Лінгвостилістичні студї, вип. 13, 2020, с. 35-52.

Hrytsevych, Yurii. "Oscar Kolberg's Folklore Records as a Space for Exploring the Dialect Phenomena (a Case Study of the Two-volume "The Khelm Region")". Linguostylistic Studies, iss. 13, 2020, pp. 35-52.

УДК 811.161.2(438)'373.4:[801.81:398]

https://doi.org/10.29038/2413-0923-2020-13-35-52

\title{
ФОЛЬКЛОРНІ ЗАПИСИ ОСКАРА КОЛЬБЕРГА ЯК ПРОСТІР ВИЯВУ ДІАЛЕКТНИХ ЯВИЩ (на матеріалі двотомника «Chełmskie»)
}

\author{
Юрій Грицевич \\ Волинський національний університет імені Лесі Українки, \\ Луцьк, Україна
}

У статті проаналізовано діалектні лексичні одиниці, засвідчені в записах холмського фольклору другої половини XIX ст. відомого польського етнографа О. Кольберга (1814-1890). Здійснено опис найменувань за лексико-семантичним принципом. Інформаційний потенціал фактажу дозволив сегментувати аналізовані діалектизми на 12 тематично розмаїтих груп, які досить повно репрезентують лексику поняттєвого поля «Людина та її риси», повсякденної господарської діяльності, побуту, природи, матеріальної й духовної культури та ін. Констатовано, що окресленими сферами, а в їх межах лексико-семантичними групами не вичерпується функціонування діалектизмів, однак вони найбільш репрезентативні.

Ключові слова: фольклорні тексти, діалектна лексика, номен, лексикосемантична група, Холмщина.

\section{OSCAR KOLBERG'S FOLKLORE RECORDS AS A SPACE FOR EXPLORING THE DIALECT PHENOMENA (a case study of the two-volume «The Khelm region»)}

\author{
Yurii Hrytsevych \\ Lesya Ukrainka Volyn National University, Lutsk, Ukraine
}

The Ukrainian-Polish border-line region opens up a lot of research prospects, especially when it comes to the territories of the so-called Zakerzonie region, namely Kholmshchyna, Nadsiannia and Lemkivshchyna. They are of particular interest in terms of their location and combination of several cultures since they were the westernmost regions of the Ukrainians living within ethnographic areas. As a result of the tragic events of the first half of the twentieth century, related to the relocation of the interstate border and the resettlement of the indigenous ethnic groups from the places of their autochthonous residence the Polish and Ukrainian populations now live both on the territory of their own country and in the neighboring country, where they are one of the national minorities. A wellknown Polish folklorist and ethnomusicologist Oscar Kolberg (1814-1890) managed to record and partially publish in the second half of the 19th century the folklore materials of the Khelm region, lost due to the later forced resettlement of the autochthons.

(C) Грицевич Ю., Волинський національний університет імені Лесі Українки, 2020.

Це стаття відкритого доступу на умовах CC BY-NC 4.0 
Indicative features of the methodology of this tireless collector of folk art were the philological accuracy and completeness of the recorded from the mouth of the respondent material with the phonetic transcription to convey all the nuances of speech. Many border areas have undergone significant changes in their ethnic composition since 0. Kolberg's recordings, so the folklore and ethnographic materials recorded by an authoritative Polish researcher are almost the only source of reconstructing the life, customs, and firstly, an authentic speech of the population of these regions. The article analyzes the dialect lexical units attested in the records of the Khelm folklore of the second half of the XIX century, revealed by Oscar Kolberg. The author focuses on the description of names according to the lexical-semantic principle. The information potential of the materials allows segmenting the lexical units into 12 thematically diverse semantic groups which quite fully represent the vocabulary of the conceptual field of a Human and his/her Features, Daily Economic Activity, Life, Nature, Material and Spiritual Cultures, etc. The functioning of the dialect units is not limited to the outlined spheres and to the lexical-semantic groups within them, but they are the most representative.

Key words: folklore texts, dialectical vocabulary, nomen, lexical-semantic group, Kholmshchyna.

Вступ. Польсько-українське пограниччя - цікавий, дуже перспективний, але й почасти суперечливий із мовознавчого погляду ареал. Ідеться насамперед про Холмщину - територію на захід від середини Західного Бугу, яка на заході межує з Люблінщиною, на сході - з Волинню, на півночі з Підляшшям, на півдні - з Галичиною. Зацікавлення місцевими говірками започатковано ще в XIX ст. У цей період з'являється фундаментальна праця В. Шимановського «Звуковые и формальные особенности народных говоров Холмской Руси». Історію наукового вивчення холмських говірок скрупульозно проаналізував відомий славіст М.Лесів у монографії «Українські говірки в Польщі». І. Митнік комплексно дослідила антропонімію Холмщини XVI-XVII ст. Ж. Масюк зосередила увагу на літературній онімії у творах про долю холмщан на матеріалі текстів відомого волинського письменника Й.Струцюка, дитинство якого минуло в Грубешівського повіту за 29 км від Холма. У численних працях Н. Осташ запропоновано системний різноаспектний опис структурних рівнів говірки села Березна. Студіюванню холмських говірок присвячено також праці Г. Аркушина, В. Мойсієнка, Р. Осташа, Л. Фроляк, Ф. Чижевського та ін.

Постійний науковий інтерес виправданий не лише з погляду цінного лінгвістичного матеріалу, але й тим, що носії цих говірок були депортовані зі своїх рідних земель у середині XX століття через сумнозвісну операцію під кодовою назвою «Вісла» - завершальний етап депортацій, який полягав у примусовому виселенні українців з Лемківщини, Надсяння, Підляшшя і Холмщини на західні та північні землі Польської держави, що до 1945 року належали Німеччині. 9 вересня 1944 р. у Любліні була підписана «Угода між урядом Української Радянської Соціалістичної Республіки i Польським Комітетом Національного визволення про евакуацію українського населення 3 території Польщі і польських громадян з території УРСР». Реалізація договорів зумовила депортацію 
громадян української, білоруської, російської, русинської національностей із Надсяння, Лемківщини, Холмщини й Підляшшя на територію Української РСР, натомість поляків та євреїв (які були польськими громадянами) із західних областей УРСР - у Польщу. Відповідно до цієї угоди переселено понад 500 тис. осіб. Депортація призвела до руйнування осілості та надзвичайно ускладнила процес збереження культурних надбань холмщаків, зокрема фольклору. У лютому 2007 року Президент Польщі Лех Качинський і Президент України Віктор Ющенко в спільній заяві засудили акцію «Вісла», а 5 квітня 2007 року Віктор Ющенко підписав Указ № 274 «Про заходи до 60-х роковин операції „Вісла”», де примусове переселення етнічних українців названо страшними подіями в історії України.

Інформацію про специфічні риси місцевих говірок можна черпати 3 фольклорних збірників, звичайно, за умови, що фіксація такого фактажу передбачала послідовне й точне відтворення діалектних рис усіх мовних рівнів. У 1986 р. відомий фольклорист і мовознавець із Любліна І. Ігнатюк так оцінив стан досліджень української культури в Польщі: «Найменше фольклорних матеріалів поміщено з Холмщини. Це тому, що на цій території після війни тільки де-не-де залишилися невеличкі групи українського населення, а також немає там кому збирати й досліджувати фольклор. Про фольклор Холмщини були надруковані ось такі статті. Покійний Євген Самохваленко надрукував у „Нашій культурі” (№ 1, 1958) статтю під заголовком „Доля жінки в холмській народній пісні”. (...) 3 цієї території тільки А. Зарчук зібрав та помістив у Нашій культурі (89 і 90 номери за 1965) 21 приказку, а Олександр Волинець надрукував в Українському календарі за 1969 р. статтю під заголовком „Старі пісні на Холмщині", в котрій подав уривки кількох весільних весняних та інших пісень, що їх сам записав в околицях міста Грубешова. Також Український календар за 1973 р. надрукував фольклорні матеріали під заголовком „3 весільних пісень і приспівок села Гунятин Грубешівського повіту"» (Ігнатюк 76).

Втрачені через пізніше примусове відселення автохтонів фольклорні матеріали Холмщини встиг зафіксувати й частково опублікувати в середині XIX століття відомий польський фольклорист та етномузиколог 0. Кольберг (1814-1890). Показовими рисами методики цього невтомного збирача народної творчості були філологічна точність та повнота запису матеріалу з уст респондента з фонетичною транскрипцією для передачі всіх мовленнєвих нюансів. Багато порубіжних теренів від часу записів 0 . Кольберга зазнали значних змін свого етнічного складу, тому фольклорноетнографічні матеріали, зафіксовані авторитетним польським дослідником, є чи не єдиним джерелом реконструкції побуту, звичаїв і насамперед автентичного мовлення населення цих регіонів. 
Матеріал дослідження. В основі дослідження - фольклорні тексти, співвідносні з холмським говірковим ареалом, записувачем та редакторомупорядником яких виступив О. Кольберг.

А. Квілецький у вступному слові до першого тому тритомника «Sanockie - Krośnieńskie» 0. Кольберга пише про поділ наукової спадщини видатного фольклориста на дві частини: «Do pierwszej zaliczyłbym te opracowania i notatki, które w przypadku jakichś nieścisłości, sprzeczności bądź niejasności dają się stosunkowo łatwo skorygować czy wytłumaczyć w oparciu o dzisiejsze postępowanie weryfikacyjne $\mathrm{w}$ terenie (lub $\mathrm{w}$ oparciu o inne współczesne Kolbergowi dane etnograficzne); druga część dorobku to ta, której uzupełnienie lub konfrontowanie z wynikami obecnych studiów terenowych jest trudne lub zgoła niemożliwe, gdyż zaistniałe po Kolbergu wydarzenia historyczne i przemiany społeczne zmieniły całkowicie strukturę i charakter opisywanych okolic» (Kolberg, Dzieła 49: V). Якщо перша частина умовно складається зі збірників, у яких зафіксовано народну творчість тих регіонів, що зберегли тяглість фольклорної традиції, то друга частина охоплює місцевості, які з огляду на значні міграції, примусові депортації населення настільки змінили свою етнічну структуру, що автентична культура місцевого люду опинилася під загрозою цілковитого зникнення. До другої частини зараховуємо, зокрема, записи О. Кольберга, вміщені у двотомнику «Chełmskie», адже більшість холмщаків, які населяли цей регіон, були переселені, місцевість фактично повністю втратила корінне населення. Разом з тим зникли своєрідні звичаї, давні обряди, пісні, танці, ігри. Така історична доля автентичного місцевого фольклору значно підвищує цінність записів О. Кольберга.

Мета пропонованої розвідки - дослідити лексико-семантичні групи діалектної лексики в записах Оскара Кольберга. Поставлена мета передбачає розв'язання таких завдань: 1) виявити лексичні діалектизми у фольклорному матеріалі; 2) визначити семантику зафіксованих слів; 3) здійснити класифікацію діалектних номенів за типом семантики; 4) встановити генезу досліджуваної лексики.

Методи дослідження. Основний метод узагальнення спостережень дескриптивний, за допомогою якого систематизовано та експліковано фольклорний матеріал. Частково використано прийоми внутрішньої та зовнішньої реконструкцій (залучення мовних елементів різної давності та матеріалу споріднених мов, щоб з'ясувати походження холмських діалектизмів).

Результати дослідження та дискусія. Найбільше номінативне вираження у фольклорних записах О.Кольберга має поняттєве поле «Людина та їі риси». Аналізована тематична група вирізняється як кількісно, так і різноманітністю засобів номінації. Зокрема, виділяємо назви осіб за ознакою спорідненості та свояцтва: czelad' - члени однієї родини, пор.: «Tach tach krutyła sia, uwywała po chaté, weczeru waryła, a nat' jéji czelad' musyła szcze buty w roboty» (Kolberg, Dzieła 34: 123) - продовжує 
псл. čel'adb, утворене від *čelь (пов’язаного з с̌elo, укр. чоло́, čelověkъ, укр. чоловік) за допомогою збірного суфікса -jadb (-е̌db); далі зіставляється 3 коліно, покоління; непереконливою, на думку етимологів, видається спроба тлумачити псл. čel'adb як похідне від трансформованого l'udz 3 підсилювальним префіксом с̌е- (Етимологічний 6: 293).

Натрапляємо на вживання номінацій, які кваліфікують особу-діяча: postadnyca - жниця, яка випереджає інших женців у роботі, пор.: «Mij snop wojewoda (pierwszy) chodyt koło horoda; mij snop ostałec (ostatni, pozostały) powede postadnycu $w$ tanec» (Kolberg, Dzieła 33: 165) - первісне поста́тниия похідне від по́стать «смуга поля, яку займають женці», що утворилося за допомогою префікса по- і суфікса -ть від дієслова стати; первісне значення «та, що (перша) займає постать» (Етимологічний 4: 536); пор. також з фіксацією Вітольда Дорошевського: postatnica - gw. żniwiarka przodująca grupie żniwiarzy; postacianka, przowodnica: Postaciq nazywa się cały rząd żniwiarzy i przestrzeń pola za zbożem, którq oni zajmujq̨: postatnica oczywiście bierze swa nazwę od tego, że prowadzi niejako cała postać (Słownik, Doroszewski); peredojizda - той, хто їде попереду; провідник, пор.: «Peredojizdu wytajte a nam czerewyczky dajte» (Kolberg, Dzieła 33: 202).

Серед назв осіб, які репрезентують обрядову автентику, характерним $\epsilon$ вживання лексем druchna, druchnoczka - дружка, пор.: «A my druchnoczky, hotujmo rucznyczky, rutwianyji winoczky!» (Kolberg, Dzieła 33: 262), «Nasz drużbońka wdau-sia (udał się) sim lit ne wmywav-sia, aż ośmoho roku joho druchny myli, boronoju rozczesali» (Kolberg, Dzieła 33: 338); drużba розпорядник на весіллі, пор.: «Ej kure, kure, ne pijte rano, pryjichav drużba $z$ woszcza (wojska) ne rano, pustyv konyki na pastownyky» (Kolberg, Dzieła 33: 281), «Pryjichav drużba żijty (żąć) na ślipym zerebity» (Kolberg, Dzieła 33: 290), "Nasz drużba lakowaty litaje kole chaty; zaletyv do swynyci, wün dumav szo do świtlicy» (Kolberg, Dzieła 33: 290), «Drużba myłyj! jak kony ne dostanete, na kociubach pojédete - drużba myłyj!» (Kolberg, Dzieła 33: 350) - зводиться до псл. *drugъ «товариш, приятель»; споріднене з лит. draũgas «супутник, товариш», draũg, draugè «разом, спільно», sudrùgti «приєднатися», лтс. dràugs «товариш, колега; другий член пари; інший» (Етимологічний 2: 134).

Соціальний статус особи увиразнюють лексеми myzerak - злиденна людина, пор.: “A wtocza wchodyt' pan, y każe: „tach, tach to taja samaja kobita, szoś jyj nechtiw chowaty, taja tretiaja żonka toho myzeraka"» (Kolberg, Dzieła34: 126) - запозичення з латинської мови, очевидно, через польське посередництво (п. mizerja (заст.) «убозтво, злидні; салат з огірків»); лат. miseria «лихо», miser «жалюгідний, нещасний; підлий» пов'язане з таereo «сумую», етимологічно неясним (Етимологічний 3: 473); hołysz - вбога людина; жебрак, пор.: «Takaja duszie $w$ hołyszie - jach y $w$ welykoho pana» (Kolberg, Dzieła 34: 78) - продовжує псл. golъ (Етимологічний 1: 548); zbuj розбійник, грабіжник, пор.: "Ale raz, a buły tam zbuje w tom ljisé, dywiat' sia na derwo, a tam detyna sédyt', tach jho znialy, i hodowaty, a naymenuwaly jho „Patrosyn” (Kolberg, Dzieła 34: 98), «A Patrosyn, szo wże teper bohatyj buw, tach 
daw tamtym zbujam hroszy, y wony puty wojowały, aż jomu założyły państwo» (Kolberg, Dzieła 34: 98) - полонізм; п. zbój «розбійник», zbójca «тс.» пов'язане з дієсловом zbić «розбити, побити», похідним від bić «бити» (Етимологічний 2: 248).

Особливе місце серед вербальних засобів, що характеризують людину як біологічну істоту, належить соматизмам: kryż - нижня частина спини, пор.: «Y wyjszła iz chaty, a mene szos nohy zbolyly, y kryż, tach lieh-em sobi na ławi» (Kolberg, Dzieła 34: 123) - запозичене, очевидно, через посередництво польської, чеської і словенської мов з романської мови північно-східної Італії (можливо, старофріульського або венеціанського діалекту італійської мови); лат. сrux споріднене з дінд. kruncati «гнеться», дісл. hryggr «спина», двн. (h)rukki «тс.», сірл. crūach «купа, горб» (Етимологічний 3: 90).

На фізичний стан людини, життєдіяльність організму періодично впливають різноманітні хвороби. Аналізований фактаж репрезентує такі назви захворювань: prycza - вивих ноги; хвороба, яка нападає на людину в поганих місцях, де був нечистий, пор.: «Huczy, pryczy odkydaj, odwertaj, światyj Juria! Huczu, pryczu, od bożoho chłopaczka ruczky» (Kolberg, Dzieła-34: $205)$ - очевидно, пов'язане з [при́чка] «випадок, нещасний випадок, подія, пригода» (Етимологічний 4: 584); dna - анат. матка, Uterus; захворювання органів жіночої статевої системи, пор.: «Czy dna, czy dnycia, - czy kra, czy morowycia ... żeby sobi stały na swoji porié» (Kolberg, Dzieła 34: 204) континуант псл. $d ъ n a(<d z b n a)$ з первісним значенням, імовірно, «глибина, внутрішня частина», потім «нутро, внутрішня частина людського тіла» (звідси - назви різних внутрішніх органів i, нарешті, хвороб внутрішніх органів), пов'язане з dъnо ( $є$ формою жін. роду цього ж іменника, пор. чол. рід у болг. мові $\partial ъ н$, або формою множини від dъnо) (Етимологічний 2: 95).

До репертуару мовних одиниць на позначення одягу, взуття, прикрас увійшли лексеми: pacior - намисто, прикраси, пор.: «Cikawyj do wsioho, jak cyhan do paciora» (Kolberg, Dzieła 34: 73) - запозичення з польської мови; п. paciorki «чотки, намисто» $є$ формою множини від paciorek «молитва, намистинка» (намистинками на чотках відраховується кількість прочитаних молитов); п. paciorek є демінутивом від pacierz «молитва», яке зводиться до лат. pater «батько, отець» (першого слова молитви Pater noster «Отче наш») (Етимологічний 4: 322-323); nоhawyсіе - суконні штани, пор.: «Poszowby ja tanciowaty, ta toroczki rwut' sia korotkyji nohawycie, diwczićta smijut' sia» (Kolberg, Dzieła 34: 62) - пов'язане із псл. поga «нога» (Етимологічний 4: 108); kymbałka - старовинний жіночий головний убір, що має форму півмісяця, пор.: «Szołom, szołom po dubyni, dywky winky pohubyły; mołodycie kymbałycié, a parobky nohawycié!» (Kolberg, Dzieła 34: 63) п. kibałek, kibałka (з укр.) пов'язане з [гибámu] «бгати» (первісно «згинати»; пор. гібать гібалку «закручувати волосся на обручик»); причини збереження давнього проривного $\boldsymbol{\tau}$ і послідовної заміни його глухим $\boldsymbol{\kappa}$ не зовсім ясні (Етимологічний 2: 428); ходак - постолик, пор.: «Nie widać, nie 
widać mego hajdamaka; za górq̨, za górq poprawia chodaka» (Kolberg, Dzieła 34: 63) - пор. пол. chodak 1 . but ortopedyczny bez pięty, na podeszwach z drewna i na podwyższonym obcasie; 2 . daw. lichy, prymitywny but (Słownik PWN).

Із назв страв та напоїв засвідчено номени jidło - продукти харчування; їжа, пор.: «Ałe szczoż robyty, ide, ide, nadybaje sia z kótom, szo tachoż wołoczyw sia za jidłom» (Kolberg, Dzieła 34: 122) - запозичення із західнослов'янської групи мов, пор. п. jadło «pokarm», походженням сягає iє. *ed- «їсти», псл. jasti (префіксальна звукова форма -е̌sti) < *ēsti < *ēe-ti (Етимологічний 2: 325); paluchy - млинці, приготовані перед полум'ям; маленькі вареники, пор.: «Czom и tebe, wowcze, jazyk welykyj? Jofitia - Bo ja jazykom w picz paluchy kidaju. Jofitia» (Kolberg, Dzieła 34: 40) - споріднене 3 псл. paliti, пов'язане чергуванням голосних 3 polěti «горіти, палати», *polmen- «полум'я»; - споріднене з прус. pellane «попіл», лит. pelenaĩ, лтс. pelni «тc.»; іє. *pol-, *plē, *plō «палити» (Етимологічний 4: 266); beseda вгощення, пор.: «Naroblu ja pywa, sołodkoho medu, zaproszu bratyka do sebe na besedu» (Kolberg, Dzieła 34: 55), пор. п. biesiada «бенкет», ч. слц. bieseda «дружня розмова; зібрання для розмови»; псл. besěda, утворене 3 прислівника bez «зовні» і іменника sěda «сидіння»; первісне значення «сидіння надворі», пізніше «зібрання», «розмова» і т. д. (Етимологічний 1: 176); podeszwa, podoszwa - низ короваю, пор.: «I wyno-ś wypył, i mene-ś uział, nasz sia wesołyj w znosyt', drużby o toje prosyt', żeby łaskawe béli podoszwy ne holili» (Kolberg, Dzieła 33: 328), «Nasz sia muzyka znosyt o podeszewku prosyt, żebyśte buli łaskawy, podeszewki ne krajali» (Kolberg, Dzieła 33: 122) споріднене з псл. šiti (Етимологічний 6: 421), пор. також укр. літ. підошва нижня частина взуття, якою ступають по землі, пришита або приклеєна до верху за допомогою устілки (Словник 6: 478).

Розгалуженістю номінацій відзначаються репрезентанти гіперсеми «Фауна»: dyk - дикий кабан, вепр, пор.: «Tach korol skazaw; chto zabje toho dyka, to dam jmu majontok, pól królestwa jmu bude!» (Kolberg, Dzieła 34: 98), «No, a maw wyn, toj korol sady, a wtruwyly sia buły dyk'y do toho sadu, y szkodu robyly» (Kolberg, Dzieła 34: 98), "No a teperże serednij: et, de tam, szcze dalij poszło storonóju a dyk żywyj; no, a szcze durnyj; toj jach strelyw, tach jach raz zabyw dyka, o!» (Kolberg, Dzieła 34: 98), пор. п. dzik - zwierzę z rodziny świń, cenione przez myśliwych; Sus scrofa (Słownik PWN); псл. dikъ одного кореня $з$ *divъ, *divbjь далі зіставляється з лит. dỹkas «порожній, бездіяльний», а також, менш переконливо, з кімр. dig «гнів, гнівний» (Етимологічний 2: 69); botion - лелека, чорногуз; Ciconia, пор.: «A znowu do botiona, takoż chocze strélaty; - znowu botionyw jach mhla nad nym: „ne strélaj, stanemo tobi pomahaty!» (Kolberg, Dzieła 34: 97) - запозичення з польської мови; п. bocian (з XV ст.), [bocan, bociuń, bocień, bocek, bociek, boczoń, baczoń, bucień], каш. заст. [kłobocian], як і верхньолуж. baćon, нижньолуж. bóśan, bóśon, полаб. büöt'an, büt'an (< *botěnъ, *botěni), певної етимології не має; можливо, пов'язане із звуконаслідувальним р. бо́тькать «стукати»; непереконливо пов'язувалося $з$ р.забота, заботиться (через гумористичне зближення 
вигляду замисленої людини з лелекою), з п. [kłobocian], каш. [kłobocon] від *kłobotati «стукати дзьобом», пор. лтс. klabatât «тс.» (про лелеку), вн. Klapperstorch «білий лелека», з п. bok, р. бок, укр. бік; непереконливим $\epsilon$ зведення українських та інших слов'янських форм до іє. *bhod- «колоти, бости»; можливе припущення про зв'язок з укр. бу́сол, [бузок, бусок], р. [бу́сел, бу́сол], бр. бусе́л, п. [buset, busioł] «лелека, молодий лелека» (Етимологічний 1: 240).

Мікологічну лексику репрезентовано назвою woronie ucha, пор.: «Aha! na hryby, a na jachyjiż? chyba na woronie ucha!» (Kolberg, Dzieła 34: 72), як пояснює сам О. Кольберг, це - Perizza coccinea; grzybki małe czerwone po lasach, do niczego nie przydatne (Kolberg, Dzieła 34: 72).

У межах лексико-семантичної групи апелятивних назв географічних об'єктів, ландшафтів виділяємо номени hostynieć - великий битий шлях, пор.: «Nad hostyńciom żyto metłoju zabyto, (mietlica zarosło) Mołodoho kozaczeńka na wojni zabyto» (Kolberg, Dzieła 34: 11), «A de tach idesz chłopaku? takyj szcze newelyczkyj, wże sam tach honyt' hostynciom» (Kolberg, Dzieła 34: $127)$ - продовжує псл. gostb < іє. *ghostis; споріднене з гот. gasts «чужинець, чужоземець», двн. gast «тс.», нвн. Gast «гість, чужинець, прибулець», лат. hostis початково «чужинець, гість», пізніше «ворожий, чужоземець, ворог (особливо батьківщини)» (Етимологічний 1: 517); pastownyk - пасовище, пор.: «Ej kure, kure, ne pijte rano, pryjichav drużba z woszcza (wojska) ne rano, pustyv konyki na pastownyky» (Kolberg, Dzieła 33: 281) - континуант псл. pasti; споріднене з лат. pāsco «пасу; годую; утримую; викохую», pābulum «їжа, харчі, корм» (Етимологічний 4: 485).

Діалектні назви житлових, господарських споруд, приміщень для тварин репрезентують такі діалектизми, як trachtyrnia - будинок для зупинки та ночівлі проїжджих, із шинком, де можна поїсти; закусочна, пор.: «Ot, najmu sobi trachtyrniu, budu maw trachtyrniu, budut' u mene wsi jisty y pyty budut', hraly y tanciowaly y pany budut' do mene zajiżdżaly» (Kolberg, Dzieła 34: 111) - через посередництво польської мови (traktier, traktiernia) запозичено з німецької; н. traktíeren «поводитися з ким-небудь, пригощати» (Етимологічний 5: 616); plebanja - парафія католицького священника; садиба, подвір'я, дім парафіяльного католицького священника, пор.: «A maw-że tam, $w$ tom seli ksiendz oweć caloje stado, y tach stały sobi $w$ chlewi, a ksiendz spaw iz parobkamy w plebanji» (Kolberg, Dzieła 34: 118), «No! y teperże, wylazyt' wyn toj dureń na plebanjiu, na sam werch, y kryczyt': „wstawajte, jehomostiuniu, wstawajte! wowk howeczky duszyt'!» (Kolberg, Dzieła 34: 118) запозичення з польської мови; п. pleban, як і ч. слц. заст. plebán «тс.», походить від слат. plēbānus «тс.», утвореного від лат. plēbs «простий народ, плебс; натовп»; пор. ще бр. пляба́н «парафіяльний католицький священник»; (Етимологічний 4: 435); zapoly - засіка (в клуні) для снопів; бокове приміщення в коморі, клуні для зберігання зерна, пор.: «Oj turbowaly sia zapoly (miejsca na snopki $w$ stodole), szo pustiuleńky stodoły, stodoły. Oj ne frasujte sia zapoly, zapoly, budut povnyji stodoły, stodoły» (Kolberg, 
Dzieła 33: 170) - продовжує пізнє псл. pola «половина; пола», утворене від polъ «половина, бік» (Етимологічний 4: 485).

Досить об'ємною за семним складом виявилась лексико-тематична група побутовизмів: студня - криниця без зрубу, пор.: «Na szczo w studniu szcze ljity wodu?» (Kolberg, Dzieła 34: 76), - пор. псл. studъ (studa) «прохолода, свіжість, холод, мороз», studiti «охолоджувати, прохолоджувати» (Етимологічний 5: 457); chfliszczyna - похідна пляшка; баклага, пор.: «Pojszow wyn, dostaw tam, $i$ ide wże nazad z lekarstwom we chfliszczynce» (Kolberg, Dzieła 34: 95) - фонетичний варіант давнішого фляжкк, запозиченого через посередництво польської мови з німецької; н. Flasche «пляшка» < герм. flaska «тс.» пов'язане 3 flechten «плести», яке зіставляється з псл. plesti (Етимологічний 6: 113); obrus - скатертина, пор.: «Szczo nam buły stoły - a wse to nowyji, szczo nam buły obrusy - a wse lannyji» (Kolberg, Dzieła 33: 275), "Oj wydaj bateyku korowaj! oj wydaj z nowoj komory. Oj wydaj na tisowy stoły, oj wydaj na krużaty obrusy!» (Kolberg, Dzieła 33: 206) псл. obrusz, пов'язане чергуванням голосних з цсл. бръснжти «стерти», рцсл. брусити «гладити, точити», укр. брус; викликає сумнів пов'язання 3 слц. rusat' «витріпувати краї тканини», що зводиться до гіпотетичного *rupsati «скубти», яке могло бути спорідненим з нвн. raufen, rupfen «скубти» (Етимологічний 4: 144); stoczky - залишки (краплі) горілки, пива у пляшці, які стікають до дна, пор.: «Stoczky - na doczky» (Kolberg, Dzieła 34: 78) - пор. псл. *tekti «текти», споріднене з лит. tekěti «текти, бігти», tékmé «течія, потік» (Етимологічний 5: 537); kubah - гніздо, пор.: «A tamtoho, jach wyn wykynuw, tach worony jho porwały i ponesly do ljisa do swoho kubaha, na derwo, taj wsadyly meży swoji dity» (Kolberg, Dzieła 34: 95), пор. діал. кубах - ямка для садіння городньої культури (капусти, картоплі тощо); місце під піччю для попелу; заглибина біля печі, де зберігають сіль, сірники тощо; [ку́башка] засік; заглиблення біля комина для дрібних кухонних речей (Етимологічний 3: 119); chwujara - сопілка, пор.: «Y tach jach wże wsi obstanowyly, typiro sam korol bere tuju chwujaru $w$ ruky, a wona jmu poczne hraty» (Kolberg, Dzieła 34: 99), «Oj znaty, znaty, chto żiónku maje, détynu nosyt' w chwujarku hraje» (Kolberg, Dzieła 34: 39) - польське fujara - запозичення зі східнороманських мов; рум. flúier «сопілка, флояра», молд. флу́ер «тс.» неясного походження; припускається зв'язок з лат. flābellum «віяло», що зводиться до іє. *bhle-/bhol- «надувати, набрякати», звідки, можливо, також псл. *bolna, укр. боло́на (Етимологічний 6: 112); гора - соляний розчин; пор.: «No y potom wże toje teliétko mało wtiechu z toho krupnyku, bo nycht by joho ne najiw, yno wono sia napyło sołonoj juszky jak ropy» (Kolberg, Dzieła 34: 124) - запозичення з польської мови; п. гора «розсіл, ропа; гній (у болячці); нафта; бітум», ropić «загноювати, нагноювати» зіставляються 3 лтс. rept «зарубцьовуватися», дінд. rápah «поранення, тілесне ушкодження» (Етимологічний 5: 122). Номени ódrobyna, wodrobyna вербалізують сему «крихта, крапля, частка», пор.: «Oj czis bo nam, czis - swatkowé do domu bo uże konyki zjily (zjadły) sołomu. Zjily sołomu i horochowyny, zjily konyki do 
ódrobyny» (Kolberg, Dzieła 33: 316), «Horszczar bat'ko, horszczar maty, horszczarowy treba daty. To za mysku, to za rynku, treba daty wodrobynku» (Kolberg, Dzieła 34: 73) - континуант псл. drobb, drobьnъ; - очевидно, споріднене з гот. ga-draban «вирізувати, висікати, видовбувати», дісл. draf «рештки, осколки» (Етимологічний 2: 129).

Закономірно з огляду на тематику аналізованого матеріалу вживано ритуально-обрядову лексику: wołoczobne - крашанки й писанки, які на другий день Великодня люди дають одне одному; подарунок у вигляді паски й кількох крашанок у понеділок, пор.: «Letiła sowyszcze czerez seliszcze, a bez jakoje? czerez Orchówśkoje. Prosyła dywoczok wołoczobnoho» (Kolberg, Dzieła 34: 208) - полонізм włóczebne «плата за волочіння (боронування); великодня данина в панський двір; обряд парубків на перший і другий день Великодня; подарунок за проповідь на Великдень» - похідне утворення від волочи́ти «боронувати», пов'язане з давнім святковим обрядом (Етимологічний 1: 422); boroda - жмуток невижатого збіжжя, залишений у полі, пор.: «Chto tyji borody ne pele, ne pele, tomu sia żyteńko ne stele, ne stele» (Kolberg, Dzieła 33: 170) - континуант псл. *borda (Етимологічний 1: 232); wereja - останній сніп під час жнив; завершальний етап жнив; обжинки, пор.: «Juże na polu wereje, (pusto po zbożu, obżęto), juże sia żytko nie chwieje, nie chwieje» (Kolberg, Dzieła 33: 170) - псл. *verěja пов'язане 3 *verti «зачиняти»; пор. п. [wierzaje, wierzeja, wierzaja] «одна 3 двох половин воріт» (Етимологічний 1: 355).

Значення абстрактності реалізує номен fraszka - дрібниця, дурниця, пор.: «To fraszky, - małe ptaszky» (Kolberg, Dzieła 34: 78) - запозичення 3 польської мови; п. fraszka «дрібниця» походить від іт. frasche «пустощі, жарт» (множина від frasca «вкрита листям гілка») (Етимологічний 6: 128).

Багатством і різноманітністю виявів позначений пласт ад'єктивів: praciwnyj - працьовитий; утомлений працею, пор.: «A ona każe: eh! nyc, ale wión praciwnyj, bude praciowaty, musyt' to bude mene żywyty» (Kolberg, Dzieła 34: 208) - запозичення з польської мови; п. praca «праця», ст. proca, походить від ч. práce (< práca), що зводиться до псл. діал. *portja, пов'язаного 3 *portiti «посилати» (звідки розвинулся болг. прámя «посилаю», м. праќa «посилає»), яке не має паралелей в інших індоєвропейських мовах; щодо семантики пор. схв. по̀сао «справа, робота» 3 *posъlъ, пов'язаним з *posъlati «послати» (Етимологічний 4: 557); takrócznyj, tajkrócznyj, takriócznyj - торішній, пор.: “„Et ni! wona, taikrócznoho smychu płacze!” - „Jachoż to? szoż to za takrócznyj smych?"», "A tach?! to prawdu każesz szo maje czoho takriócznoho smychu płakaty!» (Kolberg, Dzieła 34: 127) такрік - результат злиття ст. такъ рокъ (Етимологічний 5: 505); szczyrciowyj - чистий пісок; піщаний грунт, на якому нічого не родить; крупний пісок, який насипають на дороги, пор.: «Oj szczyrciowaja doroha do sadu, kudy pyjszov mołodyj Pawlusio - z posahu» (Kolberg, Dzieła 33: 256) запозичення $з$ польської мови szczyr «підгрунтя», [szczérzec] «чисте поле, пустеля»; утворення, похідне від щирий «чистий, без домішок; справжній» 
(Етимологічний 6: 510); torunkyj - численний; частий, густий; врожайний, пор.: «Ej! Ne ruchaj, Patrosyne, toho pera, bo tobi z toho torunkaja byda bude» (Kolberg, Dzieła 34: 96) - пор. торонний, торонці «тс.» (Етимологічний 5: 606); smarżystyj - смуглий, темний, пор.: "Ja tebe ne znaju, ja tebe ne widaju, szo tebe ukusyło, cy had, cy hadyna, cy sameć, cy samycia, cy smarżystaja, cy kroplystaja...» (Kolberg, Dzieła 34: 208) - сягає псл. smaga «жар, спека; вогонь», *smagnoti «сохнути, сушити; темніти», smažiti «смажити» пов'язані чергуванням голосних із *smog- (псл. [smog-orъ] «висохле болотяне коріння, торф для спалення»; пор. пол. smogórz «торф» (Етимологічний 5: 314); субстантивований прикметник choryj - хворий, пор.: «Wmawlaty komu, - jak choromu jajce» (Kolberg, Dzieła 34: 78) - пор. псл. хvorъ / хоrъ, яке виводиться 3 давнішого *suoro- ( ${ }^{*}$ suero-) «різати, колоти; наривати, гноїтися»; заміна початкового $s>x$ пояснюється впливом псл. xylъ, xylъjb (пор. р. хи́лый); висловлювалася також думка про можливість зв'язку з іє. коренем *ks- / kes- «різати, хворий» - це первісно «каліка, травмована людина» (Етимологічний 6: 168).

Цілком закономірне з огляду на частиномовну природу активне вживання дієслів: judyty - під'юджувати, пор.: «Judo, judo! (nazwisko dawane złemu) ne judy sia, w biłoje tiło ne koruny sia» (Kolberg, Dzieła 34: 216) продовжує псл. juditi, споріднене з лит. jáudytis «пустувати, буяти»; для польського judzić припускається запозичення зі східнослов'янських мов (Етимологічний 6: 519); potratyty - позбавити життя, згубити, пор.: «Tach wony prosiąt' sia na nócz, a tyji doczky każut: „ta iny by ne boronyly, my by was nóczowały, ałe jach nasza mama pryjde, to was potratyt', pohubyt' was!» (Kolberg, Dzieła 34: 114) - пор. стсл. тратити, траштж «знищувати, губити», яке зводиться до псл. tratiti, спорідненого з лит. trótinti, trótinu «дражнити; знущатися» (Етимологічний 5: 623); puknuty - стукнути, грюкнути, пор.: «A pryjichaw mój myleńkyj z Podola, z Podola, Stuknuw, puknuw w okonoczko, $z$ zastola» (Kolberg, Dzieła 34: 17), "Jach zaletyw w nowyj dwór, Puknuw, stuknuw w okoneczka, Wyjszła do nioho żona, Stara żona, maty pana» (Kolberg, Dzieła 34: 4) - продовжує псл. pqkati, pqk(nq)ti «тріскатися», очевидно, звуконаслідувального походження, паралельне до *poukati «стукати, тріскати» (Етимологічний 4: 630); podkulity, podkulyty - зігнути, зіщулитися, підібрати ноги під себе, пор.: «Oj znaty, znaty, chto wże żonaty, skulyw sia, zhorbyw sia i zażuryw sia» (Kolberg, Dzieła 34: 39), «Ałe szczoż to jehomost sobi nadumaw, ruwniaty psa do czołowika? taż wyn st'yrwo, poczuw szos, cy szczo, ta-j podkuliw ohona y poletiw» (Kolberg, Dzieła 34: 101), «A y husak każe: "ja toż né potrébuju budy", siw sobi tach na zemly, nohy podkulyw pod sebe, ta-j sédyt’» (Kolberg, Dzieła 34: 120) - полонізм kulić «зіщулювати, згинати, звивати», kulić się «згортатися в клубок», [(каш.) skulac sq] «згорнутися в клубок»; - утворення не зовсім з'ясованого походження; найімовірніше, пов'язане з п. kulawy «кульгавий», kuleć «кульгати», а також дінд. kora- «рухомий суглоб», авест. fra-kava «той, що має попереду горб», які зводяться до іє. *keu- «кривити, згинати, звертати»; пов'язується також 
з п. kula, укр. ку́ля «предмет круглої форми»; пов'язання з ч. chouliti se «стискатися, зіщулюватися, тулитися», слц. chúlit' sa «тс.», де припускається експресивне походження $c h-\left(<{ }^{*} k-\right)$, потребує додаткового обгрунтування (Етимологічний 3: 133); sztyrchaty - штрикати, пор.: «Stały sztyrchaty, a derty mamku, aż zabyly, a detynu wzialy na kryła, ta-j zanesly» (Kolberg, Dzieła 34: 98) - утворення, що виникло в результаті фонетичної видозміни дієслова [стри́ка́ти] «бризкати, прискати; колоти» (Етимологічний 6: 481); murraty - обмазувати, бруднити, пор.: «No, ale szczoż wyn dumaw szczo tach jho teper lubyty budut'; ale wony szcze hórej kriczat' na nioho, szo jmu soroczky murraje, klynut', a wtekajut'» (Kolberg, Dzieła 34: 119) - пор. нижньолужицьке muriś «мутити, каламутити»; очевидно, пов'язане з му́рий «темно-сірий або сіро-бурий в плямах» (Етимологічний 3: 536); wandruwaty - мандрувати, пор.: «A wowk do nioho: „a deż to idesz”, „ot, wandruju sobi”» (Kolberg, Dzieła 34: 121) - запозичення з німецької мови, пор. н. wandern «бродити, блукати, мандрувати», wandeln «блукати, прогулюватися» (Етимологічний 3: 380); choryty - хворіти, пор.: «Ne ja rok choryła, ne jednu hodynu, oddałaś mni $w$ lichyj ruky, ne $w$ wirnu rodynu» (Kolberg, Dzieła 34: 32); frasuwaty sia - турбуватися, журитися, пор.: «0j ne frasujte sia zapoly, zapoly, budut povnyji stodoły, stodoły» (Kolberg, Dzieła 33: 170) - запозичене з німецької мови за посередництвом польської (п. fras «турбота, клопіт, піклування», ст. frasunk, fresunk «горе, сум, скорбота»; нім. fressen «їсти, пожирати», перен. «томитися, мучитися» < свн. ver-ё33en «тс.» (Етимологічний 6: 128); dorajity - порадити, пор.: «Tach dorajiw chtós joтu, o myle pujty, takoho lékarstwa prynesty szob dity mała» (Kolberg, Dzieła 34: 32) зворотне дієслівне утворення від іменної форми ра́йца, яка виникла на польському грунті з давнішого * $r a d(ь) c a$, похідного від $\operatorname{rad}(z) i c ́$ «радити», rada (Етимологічний 5: 35).

3-поміж займенників засвідчено лише вияв tyło - стільки, пор.: «Тасh wón wże każet': „no to pujdu ja do pana, skażu, szo wy majete tyło a tyło hroszy, a mene ne chtite daty, wże pujdu do pana, do dwora!» (Kolberg, Dzieła 34: 113), «A wona sia aż zadywowa: "Wydyt'sia mni tylom soły wsypała szo zawdy, szoż to je?"» (Kolberg, Dzieła 34: 124), «Zberaje toj mak, ałe szczoż! wże dywyt' sia, sońcie wysoko, a wyn szcze yno puczku maje, deż to tylo maku wyzberaty?!» (Kolberg, Dzieła 34: 97) - пор. також матеріал статті «Słownika języka polskiego» за ред. Вітольда Дорошевського: tylo daw. gw. a) «tyle, tak wiele»: Rok nie wyszło, a nauczyłem się tylo po niemiecku i matematyki, iż profesorowałem dla nowo przybywających; b) «tylko»: Moja miłość nie będzie inna, jak tylo dla niego (Słownik (Doroszewski)).

Досить потужний пласт лексики формують адвербіальні одиниці, зокрема часу: typiro - тепер, зараз, пор.: «Ta won łychyj typiro na toje: „nat' jho zabju! zabju, a dywyty sia na neje ne choczu, y tak'y jho trymaty ne budu!» (Kolberg, Dzieła 34: 113), "Typiro sam korol bere tuju chwujaru w ruky» (Kolberg, Dzieła 34: 107) - зводиться до псл. *topьrvo, утвореного із займенника *to «те» і прикметника *pьrvo «перше» (чол. p. *pьrvъ) 
(Етимологічний 5: 547); takriók - торік, пор.: «A tach, baczte, takriók mała kawaliry, to sia śmijała, zabawlyła iz nymy; a teper, to detynu maje, to płacze, nad kołyszkóju sédywszy!» (Kolberg, Dzieła 34: 127) - такрік - результат злиття ст. такъ рокъ (Етимологічний 5: 505); bezryk - букв. на той рік, пор.: «Wżeśmo posijaly, pohoraly, pohoraly, bodajeśmo na bezryk doczekały, doczekały» (Kolberg, Dzieła 33: 170) - пор. також у виразах на безрік «назавжди»; в безрік «тс.», за безрік «дуже нескоро; ніколи», (у виразі дай боже й на безрік «дай, Боже, й на майбутнє»); - результат злиття і семантичної та фонетичної видозміни виразу *без рік «через рік» (Етимологічний 1: 163); nyhdy - ніколи, пор.: "Yпо jyj to zawdy dywno buło, szo nyhdy a nyhdy ne skydaje rukawyci iz ruky i $w$ rukawyci jiść, y wse; szoś to jyj koneczne prenykało do duszyi» (Kolberg, Dzieła 34: 100), «Aj, aj! a mené żle buło, bo mene chłop powisyw w komyné, wże nyhdy do nioho ne pójdu, i wam nakazuju, i wsim sestram nakażu, nyhdy do chłopa ne chodyty» (Kolberg, Dzieła 34: 209) - продовжує псл. nikъda «ніколи», що складається з $n i$ «ні» (пор. укр. [ни] «ні») і kъda «коли» (пор. ч. ст. $k d a$ «коли»), яке у формі гда збереглося в укр. [гдась] «колись»; збереження форм в українських говорах могло бути підтримуване впливом польської мови, пор. п. nigdy (Етимологічний 4: 85); ропо - доти, поки, пор.: «Rozwywaj sia, suchyj dube, pono moroz bude, uberaj sia, wdowyj syne, pono pochód bude!» (Kolberg, Dzieła 33: 51) - вірогідно, результат злиття прийменника по і вказівного займенника с. р. одн. оно «тс.» (чол. р. о́ний, ст. онъ), які самі становили частину еліптизованого словосполучення по оно [верем'я] «по той (час)» (Етимологічний 4: 513); puty - до того часу; поки, пор.: «A Patrosyn, szo wże teper bohatyj buw, tach daw tamtym zbujam hroszy, y wony puty wojowały, aż jomu założyły państwo» (Kolberg, Dzieła 34: 98) - очевидно, пізнє утворення, що виникло з якогось словосполучення типу по ты поры, п. po ty miasty з давнішого po tych miast (Етимологічний 4: 541); zanym - поки; до того часу, поки, пор.: «Zanym że dureń pałku sobi zdybaw, y wyłomiw, pryjszow tam wowk y zjiw tele» (Kolberg, Dzieła 34: 121), «Zanym pryjde koza do woza, to nébude i powroza!» (Kolberg, Dzieła 34:79) запозичення з польської zanim «поки, поки не», za nim «тс.» утворене 3 прийменника za займенника nim (давнього $\mathrm{im}$ ), форми орудного відмінка однини від основи j- «той» (Етимологічний 2: 234); wtocza - тоді; в той час, пор.: «Tyś wtocza tam buw jach brat mne zabyw Za toho weprji szo w horodi ryw» (Kolberg, Dzieła 34: 100), «Wtocza konie siedłaty, - jach wże na nioho siedaty!» (Kolberg, Dzieła 34: 79), "Tach jachoś nahnaw sia wtocza sobaczka, tach wyjnialy z sobaky serce» (Kolberg, Dzieła 34: 100). Історик мови, академік В. Німчук прислівники вкучи, втучи вважає залишками давніх адвербіалізованих сполук прийменників із займенниками та іменником чинъ у часовому значенні: о къ чинъ, въ къ чинъ (первісно 'під час, у час якої дії, діяння, чину') та о тъ чинъ, въ тъ чинъ (первісно 'під час, у час тієї дії, діяння, чину'), за умови втрати кінцевого -н, що стала можливою після повної деетимологізації (Німчук 72-73). Ю. Громик, авторитетний дослідник прислівникової системи Західного Полісся, твердить, що 
початкову, етимологічну структуру найточніше зберігають варіанти ко́че і то́че, виходячи 3 того, що в деяких кашубських говірках наявні прислівники koče „коли”, kote „тоді”, „беручи до уваги... також факт фіксації подібних утворень у межах території старожитнього слов'янського заселення", мовознавець реконструює праслов'янське слово *koče, зіставляючи ko- і -с̌е із питальними займенниками *kъ і *če/čь й утворені за різними схемами співвідносності з ним паралельні протоукраїнське *toče i протокашубське *kote (Громик 11).

Виявлено окремі маніфестанти підгрупи міри або ступеня вияву ознаки зі значенням вказівки на крайню верхню межу вияву ознаки: rychtyk - якраз; так само; точно, пор.: «Tach wże potom, ehe! wona pry nadiji i wyn pry nadiji! ha, a won wże takyj lychyj na toje! ale wże i czjisy wychodziat' rychtyk w samuju kosowyciu» (Kolberg, Dzieła 34: 95) - через польське посередництво (пор. п. rychtyk «якраз, точно; правильно», rychtyg, rycht, rychtycznie «тс.») запозичено з німецької мови; н. richting «правильний, вірний, відповідний», пов'язане 3 richten «направляти; готувати, влаштовувати; судити; налагоджувати; рихтувати» (Етимологічний 5: 85).

Даючи якісну характеристику процесу чи стану, прикметникову семантику репрезентує лексична одиниця markótno - страшно; моторошно, пор.: «Tach dad, a markótno mu sia szos zrobyło, szo tak smert' nese, a tut nat' hućciwyji lude» (Kolberg, Dzieła 34: 88) - запозичення з мов західнослов'янської групи, пор. п. markotny «смутний, незадоволений», як і ч. [mrkotný] «сонний, плаксивий», слц. mrkotný «неприємний, гидкий», які, очевидно, зводяться до псл * ${ }^{\circ} r k n q t i$ «меркнути, темніти» (> «похмурніти, смутніти»); пор. рос. [ма́рко́тный] «хмарний; туманний; сумний, стурбований» (Етимологічний 3: 398).

Сему «місце за розташуванням на горизонтальній осі» вербалізує прислівник wokól - навколо, довкола, пор.: «A wowk do nioho: „a deż to idesz”, „ot, wandruju sobi”, odkazuje jmu kót, a wse sia yno ohladaje za jakójim derwom, cy korczom, ałe de tam! néma wokól any żadnoho, aż skóra terpne na nym» (Kolberg, Dzieła 34: 121) - запозичення із західнослов'янських мов, пор. п. заст. okół «огороджена частина вигону або подвір'я для худоби; загорожа», ч. заст. okol «огорожа, загін», стсл. околъ «круг», походить від псл. okolъ «кругла загорожа, круг», пов'язаного з kolo «колесо, круг» (Етимологічний 4: 168).

Семантику вихідного пункту руху реалізують адвербативи zkyl, z kiul звідки, пор.: «Wstaw-em potychuleńku, wziewem puczku, szcze y dobroju soly, szom baczyw zkyl brały, bo tach na polyci stojała, y prysolywem znowu od sebe toj-że krupnyk» (Kolberg, Dzieła 34: 124), "Ja tebe ne znaju, ja tebe ne widaju, $\mathbf{z}$ kiul ty wziw sia, z kiul ty znachodywsia» (Kolberg, Dzieła 34: 205).

До прислівників міри й ступеня дії зараховуємо форму krocha - трохи, пор.: «Tach nadybaje wowka, daje jmu kawalczych chliba tach połowyciu toho szczo maw, sam jiść krocha druhyj, a wże za toje perenoczuwaw jho wowk $w$ jami» (Kolberg, Dzieła 34: 111), «No, i idut’ a stojała tam chata sobi pry dorozi, 
krocha na bocé» (Kolberg, Dzieła 34: 88) - континуант псл. troxa (trъхъ) «невелика частинка, шматочок, крихта, уламок», яке пов'язане чергуванням голосних 3 truxa «потерть»; споріднене 3 лит. traũšti «розбивати», лтс. trausle «крихкий, ламкий»; іє. *ter-, звідки псл. *terti, укр. те́рти (Етимологічний 5: 652-653).

Мікросистему службових частин мови репрезентують лексеми bez через, пор.: «Taż wyn st'yrwo, poczuw szos, cy szczo, ta-j podkuliw ohona y poletiw, a ja chtiwem za nym bez korczji, bez rowy, y płuh meni sia połomiw, $y$ palenyciu-m zhubyw!» (Kolberg, Dzieła 34: 101), «Ide bez lis, - ne szerhne (nie zaszeleści), ide bez wodu, - ne bluzhne (Światło księżyca)» (Kolberg, Dzieła 34: 81), «Pryweziono korowaj z czużoj storonońky, do swojoj rodynońky. Bez bór joho weziono, kalynońku łomiono» (Kolberg, Dzieła 33: 248); naj - хай, нехай, пор.: «Koly ne chocze psicza łapa buty spokojne na stoli, - to naj bude pod stołom» (Kolberg, Dzieła 34: 75) - можливо, вже псл. najь «нехай, облиш, дай змогу» як результат стягнення виразу пе хајі «не чіпай» (Етимологічний 4: 30); упо, іпо - тільки, лише, пор.: «Tach wony wże sia bojat', y tiszat' jho: „no, no, ne chody: my tobi wże damo zawtra, yno teper lahajmo spaty» (Kolberg, Dzieła 34: 113), «Tach, bere sia wże wiszaty, dywyt' sia, a tu wseńkoje ptactwo zlitaje sia, szczo ino je, do nioho, aż wże temno» (Kolberg, Dzieła 34: 97), «Prychodiat' wony, a to tam Jazia (jędza) sedila, ale juj samój teper ne buło w chatę, yno try doczk'y» (Kolberg, Dzieła 34: 114) - загальноприйнятого пояснення не має; тлумачиться як форма наз.-знах. в. с. р. числівника псл. *іпъ «один»; пояснюється як результат складення сполучників $i+n z$, рос. но; пов'язується з *іnъ «інший» (Етимологічний 2: 307); опо - (видільна частка) тільки, лише, пор.: «Опо Petrusia u dół spuskajut', a po welemożnoj we wsi zwony hrajut'» (Kolberg, Dzieła 34: 10), «Ne uważaj pane brate sczo hołowka hładka! Ono pudi, zapytaj sia łudi czy umitiona chatka?» (Kolberg, Dzieła 34: 10) - очевидно, продовжує псл. [ono] «тільки», утворене з вказівного компонента $о$ і частки -nо, подібно до ino $(<i+$ no) «тільки» (Етимологічний 4: 192).

Окремі лексеми слугують яскравими прикладами розширення в народному вжитку чітких семантичних меж, притаманних літературному слововжитку: musyt' - мабуть, пор.: «Tach tamtaja każe: 0 , to tobi musyt' tam dobre buty u seli, majesz zawdy szo jisty i zbiże, i sér, i mieso, a ja tut némaju, ino korinie, ho» (Kolberg, Dzieła 34: 122), пор. літ. мусити - уживається як член складеного присудка у знач. повинен, повинна, повинне, повинні (робити щось, мати якусь властивість або якість і т. ін.) (Словник 4: 830); rozwiazaty розродитися, пор.: «Hospod' doczku rozwiazaw, toj noczy daw nam Boh janioła, ałe i wona słabaja, i janioł słabyj!» (Kolberg, Dzieła 34: 219) - пор. псл. vęzati; основа vęz-, очевидно, є результатом контамінації коренів * $q z-<\mathrm{i} \epsilon .{ }^{*} a n g \hat{g}$ (пор. стсл. дзъкъ «вузький», лат. ango «звужую») і *verz-, iє. vergh - (стсл. отвръзж «розкрию, відчиню») (Етимологічний 1: 442), пор. літ. розв'язувати 1. розпускати, роз'єднувати кінці чого-небудь зв'язаного; 2. знаходити відповідь на поставлену умову (в завданні з математики, фізики, хімії і т. ін.) (Словник 8: 642). 
Висновки та перспективи досліджень. Отже, інформаційний потенціал фольклорно-етнографічних матеріалів у записах Оскара Кольберга уповажнює на кваліфікацію двотомника «Chełmskie» як цінної мовної пам'ятки другої половини XIX ст. Лексико-семантичний аналіз словникового складу показав, що досліджувані говірки - частина українського діалектного континууму. Лексична реалізація маніфестантів багатьох аналізованих сем позначена значною варіативністю на рівні фонетики, словотвору, граматики. Генетично досліджувана лексика неоднорідна: виділено назви праслов'янського походження, а також запозичення зі слов'янських (насамперед із польської) і неслов'янських мов (романських, германських (найчастіше за посередництвом польської)), що цілком закономірно з огляду на специфіку географічного розташування Холмщини. Засвоєння іншомовної лексики підпорядковане фонетичним принципам аналізованої діалектної системи. Репрезентативні тематичні групи, заманіфестовані в текстах фольклору, відзначаються різноманіттям, хоч і стосуються обмеженого кола сфер буття.

Перспективним видається розгляд граматичних явищ говіркового мовлення Холмщини з опертям на фольклорні тексти, які акумулювали розмаїтий репертуар різнорівневих мовних одиниць.

\section{Список використаних джерел}

Етимологічний словник української мови, під ред. О. С. Мельничука. В 7 т. Київ: Наукова думка, 1982-2012.

Словник української мови, за ред. І. К. Білодіда. В 11 т. Київ: Наукова думка, 1970-1980.

Kolberg, Oscar. Dzieła wszystkie. W 86 t. T. 33. Kraków: Polskie Wydawnictwo Muzyczne; Warszawa: Ludowa Spółdzielnia Wydawnicza, 1964.

Kolberg, Oscar. Dzieła wszystkie. W 86 t. T. 33. Kraków: Polskie Wydawnictwo Muzyczne ; Warszawa: Ludowa Spółdzielnia Wydawnicza, 1964.

Słownik języka polskiego. PWN. URL: https://sjp.pwn.pl/.

Słownik języka polskiego, pod red. Witolda Doroszewskiego. URL: https://sjp.pwn.pl/doroszewski/lista.

\section{Sources}

Etymolohichnyi slovnyk ukrainskoi movy, edited by O. S. Melnychuk. 7 vols. Kyiv: Naukova dumka, 1982-2012.

Slovnyk ukrainskoi movy, edited by I. K. Bilodid. 11 vols. Kyiv: Naukova dumka, 1970-1980.

Kolberg, Oscar. Dzieła wszystkie. W 86 t. T. 33. Kraków; Warsaw, 1964.

Kolberg, Oscar. Dzieła wszystkie. W 86 t. T. 34. Kraków; Warsaw, 1964.

Słownik języka polskiego. Wydawnictwo Naukowe PWN. sjp.pwn.pl/

Słownik języka polskiego, pod red. Witolda Doroszewskiego. sjp.pwn.pl/doroszewski/lista.

\section{Список використаної літератури}

Аркушин, Григорій. «Деякі діалектизми в мові переселенців з Холмщини». Ze studiów nad gwarami wschodniosłowiańskimi w Polsce. Rozprawy slawistyczne. 12, Lublin: UMCS, 1997, s. 33-8.

Громик, Юрій. Прислівники відзайменникового походження у західнополіських говірках української мови. Автореф. дис. ...канд. філол. наук: 10.02.01. Київ, 1999. 
Ігнатюк, Іван. «Фольклор Підляшшя і Холмщини на сторінках пресових органів УСКТ». Украӥнський календар, Варшава, 1986, с. 76.

Лесів, Михайло. Українські говірки в Польщі. Варшава: Український архів, 1997.

Масюк, Жанна. Літературна онімія у творах про долю холмщан (на матеріалі текстів Й. Г. Струцюка). Автореф. дис. ...канд. філол. наук: 10.02.01. Луцьк, 2014.

Митнік, Ірена. «Говір мешканців Холмщини. Ч. 1: словник весільної лексики». Тенденції розвитку української лексики та граматики, ч. 2, Варшава; Івано-Франківськ, 2015, c. 146-61.

Митнік, Ірена. «Говір мешканців Холмщини. Ч. 2 : словник побутової лексики». Тенденції розвитку української лексики та граматики, ч. 3, Варшава; Івано-Франківськ, 2016, c. 46-57.

Мойсієнко, Віктор. «Пам'ятка української мови з півдня Холмщини». Slavia orientalis, T. LII, № 4, Kraków: Komitet Słowianoznawstwa Polskiej Akademii Nauk, 2003, c. 553-62.

Німчук, Василь. Давньоруська спадщина в лексиці української мови. Київ, 1992.

Осташ, Надія. «Словозміна іменників у говірці села Березна на Холмщині (форми множини)». Лінгвостилістичні студії, вип. 2, 2015, с. 116-25.

Осташ, Надія. «Із спостережень над деякими морфологічними особливостями холмських говірок». Філологічний вісник Уманського державного педагогічного університету імені Павла Тичини, вип. 5, 2014, с. 44-50.

Осташ, Надія. «Словник діалектної лексики переселенців із Холмщини». Діалектологічні студіï. 4: Школи, постаті, проблеми, Львів: Інститут українознавства імені Івана Крип'якевича НАН України, 2004, с. 355-78.

Осташ, Надія, і Осташ, Роман. «Власні особові імена в антропонімії Холмщини». Проблеми регіональної ономастики: тези доповідей та повідомлення наукового семінару. Київ, 1994, с. 38-9.

Осташ, Роман, і Осташ, Любов. «Холмські прізвища в антропонімійному просторі України». Волинь філологічна: текст і контекст, вип. 4, 2007, с. 250-8.

Фроляк, Любов. «До питання про корпус українських текстів з Холмщини та Підляшшя: проблеми та завдання його створення». Діалекти в синхронії та діахронії: текст як джерело лінгвістичних студій, Київ, 2015, с. 413-31.

Шимановский, Василий. Звуковые и формальные особенности народных говоров Холмской Руси. Обзор с приложеним образцов народных говоров. Варшава: Типография Варшавского учебного округа, 1897.

Czyżewski, Feliks. Atlas gwar polskich i ukraińskich okolic Włodawy. Lublin: UMCS, 1986.

Czyżewski, Feliks, and Łesiów, Michał. «Bibliographia prac dotyczących gwar ukraińskich na terenie Polskie (w granicach od 1945)». Ze studiów nad gwarami wschodniosłowiańskimi w Polsce. Rozprawy slawistyczne. 12. Lublin: UMCS, 1997, s. 271-98.

Czyżewski, Feliks, and Łesiów, Michał. «Słownictwo ludowe ukraińskiej gwary wsi Ochoża koło Chełma». Ze studiów nad gwarami wschodniosłowiańskimi w Polsce. Rozprawy slawistyczne. 12. Lublin: UMCS, 1997, s. 45-86.

Kolberg, Oskar. Dzieła wszystkie. W 86 t. T. 49. Wrocław; Poznań, 1974.

Mytnik, Irena. Imiennictwo ziemi chełmskiej w XVI-XVII wieku. Warszawa: Uniwersytet Warszawski, 2017.

Mytnik, Irena. Słownik historyczno-etymologiczny antroponimii ziemi chełmskiej XVI-XVII wieku. Warszawa: Uniwersytet Warszawski, 2017.

\section{References}

Arkushyn, Hryhorii. "Deiaki dialektyzmy v movi pereselentsiv z Kholmshchyny". Ze studiów nad gwarami wschodniosłowiańskimi w Polsce. Rozprawy slawistyczne. 12, Lublin: UMCS, 1997, s. 33-8. 
Hromyk, Yurii. The Pronominal Adverbs in West Polyssya Dialect of the Ukrainian Language. PhD Thesis Abstract. Kyiv, 1999.

Ihnatiuk, Ivan. "Folklor Pidliashshia i Kholmshchyny na storinkakh presovykh orhaniv USKT". Ukrainskyi kalendar, Varshava, 1986, p. 76.

Lesiv, Mykhailo. Ukrainski hovirky v Polshchi. Varshava: Ukrainskyi arkhiv, 1997.

Masiuk, Zhanna. Literary onomasticon in the Strutsyuk's J. G. works about Kholmshchyna. PhD Thesis Abstract. Lutsk, 2014.

Mytnik, Irena. "Dialect of residents in the Kholm territory. Part 1: glossary of wedding vocabulary". Tendentsii rozvytku ukrainskoi leksyky ta hramatyky, part. 2, Varshava; Ivano-Frankivsk, 2015, pp. 146-61.

Mytnik, Irena. "Hovir meshkantsiv Kholmshchyny. Part. 2: slovnyk pobutovoi leksyky". Tendentsii rozvytku ukrainskoi leksyky ta hramatyky, part. 3, Varshava; IvanoFrankivsk, 2016, pp. 46-51.

Moisiienko, Viktor. "Pamiatka ukrainskoi movy z pivdnia Kholmshchyny". Slavia orientalis, vol. LII, no. 4, Kraków, 2003, pp. 553-62.

Nimchuk, Vasyl. Davnoruska spadshchyna v leksytsi ukrainskoi movy. Kyiv, 1992.

Ostash, Nadiya. "Inflection of Nouns in the Lokal Dialect of the Village of Berezno, Kholm Province (Plural noun Forms)". Linguostylistic Studies, iss. 2, Lutsk, 2015, pp. 116-25.

Ostash, Nadiya. "Iz sposterezhen nad deiakymy morfolohichnymy osoblyvostiamy kholmskykh hovirok". Filolohichnyi visnyk Umanskoho derzhavnoho pedahohichnoho universytetu imeni Pavla Tychyny, iss. 5, Uman, 2014, pp. 44-50.

Ostash, Nadiya. "Slovnyk dialektnoi leksyky pereselentsiv iz Kholmshchyny". Dialektolohichni studii. 4: Shkoly, postati, problemy, Lviv: Instytut ukrainoznavstva imeni Ivana Krypiakevycha NAN Ukrainy, 2004, pp. 355-78.

Ostash, Nadiya, and Ostash, Roman. "Vlasni osobovi imena v antroponimii Kholmshchyny". Problemy rehionalnoi onomastyky: tezy dopovidei ta povidomlennia naukovoho seminaru. Kyiv, 1994, pp. 38-9.

Ostash, Roman, and Ostash, Liubov. "Kholmski prizvyshcha $\mathrm{v}$ antroponimiinomu prostori Ukrainy". Volyn filolohichna: tekst i kontekst, iss. 4, Lutsk, 2007, pp. 250-8.

Froliak, Liubov. "About the corpus of texts of pidliassia: problems and tasks of its creation". Dialekty $v$ synkhronii ta diakhronii: tekst yak dzherelo linhvistychnykh studii, Kyiv, 2015, pp. 413-31.

Shymanovskij, Vasilij. Zvukovye i formal'nye osobennosti narodnyh govorov Holmskoj Rusi. Obzor s prilozheniem obrazcov narodnyh govorov. Varshava, 1897

Czyżewski, Feliks. Atlas gwar polskich i ukraińskich okolic Włodawy. Lublin: UMCS, 1986.

Czyżewski, Feliks, and Łesiów, Michał. "Bibliographia prac dotyczących gwar ukraińskich na terenie Polskie (w granicach od 1945)". Ze studiów nad gwarami wschodniosłowiańskimi $w$ Polsce. Rozprawy slawistyczne. 12. Lublin: UMCS, 1997, s. 271-98.

Czyżewski, Feliks, and Łesiów, Michał. "Słownictwo ludowe ukraińskiej gwary wsi Ochoża koło Chełma". Ze studiów nad gwarami wschodniosłowiańskimi w Polsce. Rozprawy slawistyczne. 12. Lublin: UMCS, 1997, s. 45-86

Kolberg, Oskar. Dzieła wszystkie. W 86 t. T. 49. Wrocław; Poznań, 1974.

Mytnik, Irena. Imiennictwo ziemi chełmskiej w XVI-XVII wieku. Warszawa: Uniwersytet Warszawski, 2017.

Mytnik, Irena. Słownik historyczno-etymologiczny antroponimii ziemi chełmskiej XVI- XVII wieku. Warszawa: Uniwersytet Warszawski, 2017. 